Why do we dream?

\title{
梦的奇幻与真实
}

郭菲，陈祉妍 ${ }^{*}$

中国科学院心理健康重点实验室(中国科学院心理研究所), 北京 100101

* 联系人, E-mail: chenzy@psych.ac.cn

2017-09-04 收稿, 2017-11-04 修回, 2017-11-06 接受, 2017-12-19 网络版发表

摘要梦是人们最为普遍的经验之一, 由于其栩树如生和离奇的特点, 人类很早就对这种现象充满了好奇. 为 什么会做梦这个谜题在科学技术不断发展的同时也得到了更为广泛的研究. 作为一种古老的生理心理现象, 梦是 否具有适应性的功能引发了丰富的理论思考, 而对于其功能性在于做梦这种形式还是梦境的内容还需要更多的研 究予以解答. 对于梦的科学研究已从聚焦于非快速眼动睡眠扩展到了整个睡眠阶段. 而梦作为一种特殊的意识状 态, 其与清醒状态在现象学和大脑活动上的异同, 将为了解人类意识提供重要的信息, 特别是清醒梦这种兼具清 醒和睡眠特点的状态，为揭示意识的神经机制提供了独特的机会. 此外梦的研究对于临床心理和精神问题也有实 践意义. 梦的研究面临着很多方法上的挑战, 解开梦的奥秘需要整合现象学、神经科学、临床研究等多个领域的 设计和方法.

关键词梦, 做梦, 睡眠, 意识, 神经科学

2017年的诺贝尔生理学或医学奖授予了3位发现 控制昼夜节律或称生物钟分子机制的科学家．睡眠 是昼夜节律中的重要一环, 人的一生大约有 $1 / 3$ 是在 睡眠中度过的, 睡眠与人们的生理机能、认知功能和 心理健康都有着重要联系. 睡眠受到生物钟的调 节 $^{[1]}$, 此间大脑在两种不同的状态下进行周期性地切 换, 即非快速眼动睡眠 (non-rapid eye movement sleep, NREM) 和快速眼动睡眠 (rapid eye movement, REM) ${ }^{[2]}$, 两种状态在眼动、肌电和脑活动上呈现显著的差异 ${ }^{[3]}$. NREM睡眠时呼吸和心率缓慢且有规律, 血压降低, 这期间睡眠由浅人深分为3个阶段：NREM1, NREM2 和NREM3, 或称睡眠 I 期、睡眠 II 期、睡眠III期 ${ }^{[4]}$. NREM1是清醒与深睡眠的过渡阶段或睡眠的初始阶 段; NREM2可贯穿整晚的睡眠过程, 脑电波呈现独 特的纺锤波和间或的慢波; NREM3多出现于前半夜, 这期间脑电呈现典型的 $\delta$ 波, 这阶段也称为慢波睡眠 (slow wave sleep, SWS)或深睡眠(deep sleep). REM睡
眠又称异相睡眠，大脑波形近似清醒的状态，以 $\theta$ 波 为标志，这期间眼球呈现快速的运动，同时伴随着心 率和呼吸加快 ${ }^{[5]}$. NREM与REM交替出现，每交替一 次构成一个睡眠周期, 每个周期持续 $90 \mathrm{~min}$ 左右 ${ }^{[6]}$.

梦在睡眠期间的不期而至是人们最普遍和常见 的经历, 无论何种性别、种族、文化的个体几乎都有 过这种论埛光怪又栩栩如 “真”的体验，梦也是人类 历史上最为引人人胜并受到孜孜探索的现象之一. 历史上科学相对不发达时，梦更多具有奇幻和神秘 的色彩, 并被广泛用于文学艺术中, 在哲学中被赋予 深刻玄妙的隐喻，如先秦著名哲学家庄子曾借自己 的梦境提出: “昔者庄周梦为蝴蝶, 栩栩然蝴蝶也, 自 喻适志与，不知周也. 俄然觉，则蓫蓫然周也. 不知 周之梦为蝴蝶与, 蝴蝶之梦为周与? 周与蝴蝶, 则必 有分矣. 此之谓物化”(《庄子·齐物论》), “庄周梦蝶” 成为一个流传千年的哲学命题. 据考证, 梦的古字 “夢”早在盘庚时期，即“第一期”甲骨文的残片中即已

引用格式: 郭菲, 陈祉妍. 梦的奇幻与真实. 科学通报, 2018, 63: 22-31

Guo F, Chen Z Y. The bizarreness and reality of dreams (in Chinese). Chin Sci Bull, 2018, 63: 22-31, doi: 10.1360/N972017-00944 
出现 ${ }^{[7]}$. 远在两河流域美索不达米亚的尼尼微国, 大 约在公元前 3000 年甚至更早也开始了对梦的记录 ${ }^{[8]}$. 人类始终保持着对梦的痴迷, 我们为什么会做梦? 梦到底是有功能、有意义的, 还仅仅是我们大脑中的 “噪音”? 不同社会、不同文化都有对梦的理论和解 释, 随着科技的发展, 我们对于梦有了更多的认识. 尽管如此, 距离可以回答 “为什么会做梦”这个问题, 仍有很长的道路. 近几年研究手段的改进特别是神 经生理学和神经影像学方法上的进展让我们得以对 梦及做梦的神经生理基础有更深人的了解, 也为思考 睡眠和意识的问题提供了新的思考角度. 尽管梦境是 奇幻的, 但其神经基础是真实可进行科学研究的.

\section{1 梦的形式和梦的内容哪个更具功能性?}

梦是发生于睡眠期间的心理活动, 在漫长的进 化历史中保留至今, 按照达尔文物竞天择自然选择 的观点, 做梦这种现象得以延续其在自然选择上应 该有生物学的意义 ${ }^{[9]}$. 做梦的相关理论多少具有进化 学的色彩, 不过在具体内容上它们又有所区别, 其中 的一些理论强调做梦这个过程的作用, 不看重做梦 的内容, 而另一些则认为梦到了什么本身也是有功 能性的.

关于梦的几个重要早期理论(20世纪70 80年代) 多认为, 梦的内容并不具生物学的功能性. 如激活合成理论(Activation-Synthesis Theory), 该理论强调 梦里生动怪诞的影像都是随机的, 睡梦中脑干产生 的随机信号, 如脑桥-膝状体-枕叶 (pons-getliculateoccipital, PGO)脑波, 激活了前脑(forebrain), 前脑试 图整合这些随机的活动的意义, 从而合成了梦的影 像. 这个理论假设做梦是一个自动的过程, 而这些梦 的影像本身或意识的内容如同电脑在处理信息时发 出的噪音不具有功能性 ${ }^{[10,11]}$. 另外一个理论基于的 是大脑神经网络, 称为 “反向学习机制”(reverse learning mechanism), 该理论认为做梦其实是一个矫 正消除 “错误” 神经突触联结的过程, 大脑在日常生 活和学习中形成的错误突触联结, 会干扰正常的认 知活动, 梦里奇幻古怪的形象生成于超载的神经网 络, 在睡眠状态下通过PGO波产生的随机信号刺激 神经网络, 从而对那些错误的神经连接进行修剪, 而 梦中的形象只不过反映了记忆的消除过程 ${ }^{[12,13]}$. Foulkes ${ }^{[14]}$ 的认知心理学理论(Cognitive Psychological
Theory)则认为, 做梦是由于睡眠中语义和情境记忆 的随机的弥散活动. 他认为做梦时记忆的活动和梦 是随机的, 因此梦的内容不具有适应性的功能. 另有 研究者认为做梦只是进化过程中一个副现象, 梦中 的各种感觉和心理活动主要是大脑的噪音, 并不具 有任何的生物学功能.

另一方面也存在一些重视梦内容的理论. 在心 理学领域, 早在1900年弗洛伊德发表了经典著作The Interpretation of Dreams ( 《梦的解析》), 认为梦可以 满足那些被压抑的不为社会所接受的潜意识, 梦的 变形和转化工作使得这些主题在梦中的内容得以掩 饰 ${ }^{[15]}$, 弗洛伊德通过对梦境的分析在临床工作上取 得了惊人的效果. 同为精神分析学家的 Jung ${ }^{[16]}$ 认为, 梦是通往内心的一扇隐蔽的门，做梦有助于个体的 精神平衡和达成更有意义的人生. 神经学家 Mark Solms ${ }^{[17]}$ 延续弗洛伊德的理论, 认为做梦的脑部活动 支持了弗洛伊德的驱力理论, 做梦时呈现的多巴胺 系统的激活与清醒时动机性行为时呈现的大脑激活 部位是相似的. 在此基础上研究人员进一步将精神 分析的理论和方法与当代的神经科学相结合, Solms 是最早提出神经精神分析 (neuropsychoanalysis)的学 者之一 ${ }^{[18,19]}$. 另一位研究梦的科学家 George Domhoff ${ }^{[20,21]}$ 在他梦的神经认知理论 (neurocognitive theory) 中也提出做梦与大脑的认知发展有关, 涉及 当前和过去的情绪和认知内容, 梦的内容有着重要 的心理学意义和文化功能.

最近20年提出的理论趋向认为梦具有适应性的 功能, 与学习、记忆的巩固、问题解决和情绪调节等 有关 ${ }^{[22,23]}$. 基于睡眠与记忆巩固的大量证据 ${ }^{[24]}$, 一 些研究者认为, 梦可能反映了记忆在睡眠中得到加


神经认知模型, 认为在睡眠不同阶段的梦可能反映 了不同类型记忆的巩固，包括情绪性记忆、程序性记 忆和陈述性记忆等. 另有研究者从记忆加工过程的 角度提出了梦的连续激活理论(Continual Activation Theory), 认为梦是当工作记忆进人长时记忆前处于 “临时记忆”(temporary memory)时产生的产物 ${ }^{[28]}$.

一些研究者基于梦中出现的丰富的情感元素, 认为梦对于情绪的调节和维持心理的平衡有着重要


时机，使我们可以更好地梳理头脑中的情绪记忆，同 
时可以在梦这种更为发散的情境中将负性的情绪记 忆在更为广泛的记忆网络中得到抵消和缓解 ${ }^{[31]}$, 而 哥梦是由于情感加工网络的功能异常导致的 ${ }^{[30]}$. 在 这个方向上一些研究者将梦的积极适应性功能进一 步放大, 如Revonsuo等人 ${ }^{[32,33]}$ 提出的威胁刺激理论 (Threat Simulation Theory, TST), 认为梦类似于一种 对危险的虚拟演习, 在梦中那些现实生活中可能的 威胁刺激展现出来, 给我们提供一个机会去预演面 对这些威胁时的知觉和躲避, 而梦这样一个情境并 非是真实的, 因此是无害的, 不会对做梦的人造成不 良后果.

关于梦的理论和观点十分丰富, 然而由于对梦 特别是其功能研究的困难性 ${ }^{[5]}$, 目前的研究很难给我 们一个明确的答案哪一个或哪些观点更接近梦的真 实面目, 一些学者甚至提出了在进行梦的研究时对 梦的功能设定一个虚无假设的重要性, 即抛开梦的 形式或内容, 梦可能并没有任何功能 ${ }^{[34]}$.

\section{2 “REM睡眠=做梦”？}

现代对于做梦的广泛研究开始于 20 世纪 50 年代 Nathaniel Kleitman和他的两位学生, Eugene Aserinsky 和William Dement的开创性发现 ${ }^{[35,36]}$. 他们发 现在整晚的睡眠中, 大约每隔 $90 \mathrm{~min}$ 人类会进人一个 眼球左右摆动的时期, 这期间皮层活动很活跃, 出现 了类似清醒状态时的高频低幅脑电波, 即REM睡眠. 在REM睡眠后醒来时人们往往会报告自己刚才做梦 了. 在很长的时间里 REM睡眠被认为是做梦的神经 生理指标, Kleitman等人 ${ }^{[35,36]}$ 的研究开启了科学研究 梦的新视角, 由此点燃了研究者解开梦的奥秘的希 望, 不过大量的心理生物学研究致力于探索做梦和 REM睡眠之间的关系, 并未如预期那样解开做梦的 奥秘. 相反研究显示REM睡眠并不等同于做梦, REM 睡眠期间并不一定会做梦, 如脑干损伤的病人 REM 睡眠受损，但仍报告会做梦，而前脑损伤的病人 REM睡眠正常但他们却不再能做梦了 ${ }^{[37,38]}$. 同时 NREM阶段的睡眠也会出现具有梦境般(鲜明生动的 视觉影像, 丰富的情绪情感体验, 离奇古怪的情节和 元素等)的心理活动 ${ }^{[5,39 \sim 41]}$.

目前学者们普遍认可的 “REM睡眠=做梦”公式 并不准确, 梦境般的心理活动在整个睡眠阶段都会 出现 ${ }^{[37,41]}$. 神经生理学和神经影像学的研究显示梦 中栩栩如生的视觉体验可能与高级视觉中枢的激活
有关, 在高级枕题视觉联想区(higher-order occipitotemporal visual association areas)可以观察到增强的 代谢活动 ${ }^{[42,43]}$. 梦境中丰富的情绪感受可能与情绪 加工有关的脑区 (丘脑、眀额皮层、脑桥被盖以及边 缘和旁边缘结构, 包括杏仁核和前扣带回等)的明显 激活有关 ${ }^{[44,45]}$. 睡眠时脑电节律相位同步的降低反 映了功能性切断, 可能是造成奇异梦境的原因 ${ }^{[46]}$, 此外有研究表明, REM睡眠梦中高频率出现的奇异 内容可能与后扣带回、背外侧前额叶和顶叶皮层等特 定的皮层区活动的减弱有关 ${ }^{[47 \sim 9]}$.

现阶段的一个主要问题是REM和NREM睡眠阶 段出现的梦是具有相同的还是不同的机制? NREM睡 眠的“做梦”是否真是梦. 从现象特征来看二者确实 存在着一些共同点, 比如总体上它们都与个体当前 清醒时的关注点有关 ${ }^{[50]}$, 同时在睡眠的体验中, 视 听的内容要远多于其他感觉通道的内容, 几乎在所 有的梦境中都有视觉的体验, 即使在先天失明个体 的梦中也有视觉内容 ${ }^{[51]}$, 排在视听觉之后的是前庭 觉, 而其他感觉如触觉、嗅觉、味觉等出现的概率非 常低 ${ }^{[52]}$. 此外在一些 NREM 的阶段 (如 NREM1 和 NREM2), 特别是睡眠开始时, 深夜和早晨, 梦的特 点与REM睡眠阶段的梦非常相似 ${ }^{[53 ~ 55]}$. 但同时 REM 睡眠的梦在上述 3 个特点上表现得更为突出, 如内容 更生动，情节更离奇，有很多对于真实对象的扭曲、 分解、时空的错位和奇怪的组合, 充满了奇幻的色 彩 ${ }^{[5,56]}$, 而且这些梦境具有故事性, 人们往往能比较 详尽地叙述自己在REM睡眠期间做的梦. 而NREM 睡眠期间的梦往往内容是碎片化的, 但更具概念性、 更合理, 也具有更多思考性的特点 ${ }^{[47,57]}$.

基于REM和NREM睡眠的阶段梦境的异同，对 于梦的形成出现了 3 种不同的模型阐述. 首先是“单 生成”模型(one-generator model), 这类模型主张睡眠 的所有阶段都是同一组机制形成的 ${ }^{[14]}$. 最近的一项 高密度脑电(high-density electroencephalographic, EEG) 研究与这个模型存在一致性. 该研究表明不论是 REM睡眠还是NREM睡眠过程中的做梦均与顶枕叶 后部低频脑活动的减弱和高频脑活动的增加有关, REM和 NREM睡眠的做梦似乎有着共享的脑机制, 受同一脑区影响 ${ }^{[58]}$. 与之相对的模型是“双生成”模 型(two-generator model), 该模型认为梦的心理内容 是由生理状态决定的, REM和NREM两个睡眠阶段在 生理上包括大脑活动的差异决定了这两个阶段所产 
生的梦境具有质的差别, 脑成像研究发现与 REM睡 眠阶段相比, NREM睡眠阶段会表现出全脑能量代谢 的下降 ${ }^{[47]}$. 支持 “双生成” 模型的研究者认为总体而 言NREM的梦不具备REM梦的典型特点, 这些特点 包括幻觉性的影像(hallucinoid imagery), 梦中的影像 高度视觉化且非常逼真; 叙事性的结构 (narrative structure), 梦境是结构化的, 如故事一般; 高度的情 绪性(hyperemotionality), 梦中伴随丰富而强烈的情 绪体验; 认知的离奇性 (cognitive bizarreness), 比如 梦中时空的错乱; 妄想的接纳度 (delusional acceptance), 梦中是否对荒诞的现象信以为真; 以及记 忆内容的缺失 (deficient memory of content), 通常记 不住梦的所有内容 ${ }^{[59,60]}$. 这些特点反映了 REM睡眠 阶段某些脑区与NREM或清醒时相比不同的激活程 度 (如前所述的高级枕颞视觉联想区、丘脑、边缘系 统等). 第三个模型是 “隐蔽 REM睡眠” 模型 (covert REM sleep model), 这个模型认为NREM睡眠虽然不 具备REM睡眠的典型特点, 但是显示出 REM睡眠的 某些特征, 可能是REM睡眠的某些神经生理过程以 一种隐秘的方式刺激了 NREM睡眠期间的心理活 动 ${ }^{[37,53]}$. 研究发现, 在REM和NREM两个睡眠状态之 间有一段被称为 “中间睡眠”(intermediate sleep)的时 期, 兼具REM和NREM脑电的特点, 尽管这期间的梦 在幻觉性上低于 REM 睡眠阶段的梦 ${ }^{[37]}$. 此外, NREM1阶段睡眠开始时的脑电与REM睡眠的脑电具 有相似性. 不过睡眠开始这段时间的心理状态到底 是不是属于睡眠的梦仍存在争议, 如有神经影像学 的研究显示这阶段的状态更接近清醒的状态 ${ }^{[61]}$.

对梦的神经基础的研究已不拘于REM睡眠, 基 于NREM睡眠的研究在不断增加, 尤其是对 N1和 N2 两个阶段的研究. 不过由于这两个阶段本身的复杂 性且与梦的相关并不够高, 如根据EEG的形态和模 式, N1阶段可划分为若干子阶段: (1) $\alpha$ 波, (2) 间歇 $\alpha$ 波 $>50 \%$ ，(3) 间歇性 $\alpha$ 波 $<50 \%$ ，(4) 平缓 EEG（<20 $\mu \mathrm{V}),(5) \theta$ 涟渏波, (6) 单峰波 $(<200 \mu \mathrm{V})$, (7) 多峰波 $(<200 \mu \mathrm{V}),(8)$ 多峰波伴有不完全纺锤波 ${ }^{[62]}$. 大脑在 这一阶段呈现高度动态的变化状态. N2期间梦的报 告率仅为 $40 \%{ }^{[37]}$, 关于梦的研究需要更为细致地探 索NREM睡眠不同阶段包括子阶段的机制. 尽管目 前更复杂的设计和更先进的技术进一步揭示了把 REM睡眠等同于做梦的局限性 ${ }^{[63]}$, 然而鉴于REM睡

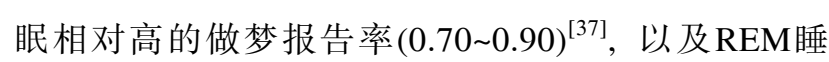
眠期间心理活动的具有典型的梦的特点, 一些学者 认为 REM睡眠仍然是目前研究梦的最好和最客观的 神经生理指标 ${ }^{[62,64]}$. 不过没有报告梦并不等于没有 做梦 ${ }^{[65]}$, 不能仅因NREM阶段较低的做梦报告率而 降低这一阶段梦研究的重要性, 通过结合NREM梦 的内容、记忆的过程、与REM脑活动的对比, 能更好 地探索做梦的机制.

\section{3 做梦与清醒是连续的还是非连续的?}

现代科学对梦的研究的意义不仅在于揭示梦本 身的奥秘, 还在于有助深刻理解人类的意识 ${ }^{[40,66]}$. 梦 是一种发生于睡眠期间的意识状态 ${ }^{[50]}$. 做梦的时候, 人类的大脑与环境的联系暂时减弱, 外部物理环境 刺激和机体与环境互动对大脑造成的束缚和影响降 低, 因此梦被认为是意识的一种更纯粹的形式 ${ }^{[67]}$.

梦和清醒这两种意识形态是连续的 (continuity) 的还是间断的(discontinuity)? 一直以来是梦研究领 域争论最为激烈的领域之一. 连续假说的学者认为 梦, 尤其是梦的内容是由清醒时的真实生活中的经 验、设想或关切合成的 ${ }^{[68,69]}$, 甚至可能梦是清醒意识 的自然延伸 ${ }^{[70]}$. 非连续假说的学者则认为梦和清醒 状态是不同的神经调节物质产生的不同模式的体验, 其中具代表性的是原型意识理论(Protoconscousness Theory), 这个理论认为做梦属于初级意识, 清醒属 于次级意识, 梦是构建清醒状态的重要材料, 梦可以 预测和发展清醒意识 ${ }^{[71]}$.

从梦的现象学上来看, 这两个理论均获得了一 定的支持. 在大多数梦中, 梦境与现实世界是很相似 的, 高度视觉化, 梦中的内容体现了现实的分类和属 性 $^{[37,41]}$. 梦反映出的个体的兴趣、人格、社会互动总 体上与清醒状态是一致的 ${ }^{[14,68]}$. 但从另一方面来看, 梦中的事物和场景常常带有离奇、不合理的特点, 会 出现一些在现实清醒状态下不会感知到或不存在的 特点, 而这些带有妄想色彩的内容在梦里我们是容 许的, 做梦的时候我们并不觉得它们有多奇怪 ${ }^{[72]}$.

神经生理和神经影像学研究表明清醒时的状态 与做梦时的脑机制有很多重叠的特点 ${ }^{[62,73]}$. 有研究 者认为尤其是内侧前额叶皮层和内侧题叶, 即使在 NREM睡眠脑血流急剧下降的时候仍然保持着相当 的激活水平, 做梦与清醒一样都属于意识连续体上 
的一部分 ${ }^{[74,75]}$. 不过另一方面做梦和清醒时一些脑 区的活跃程度存在着显著的差异, 如某些脑区在 REM睡眠时活动的降低, 如后扣带回、顶叶下回、眀 额皮层以及背外侧前额叶皮层等 ${ }^{[63]}$. 一些在先天残 疾人士中所做的研究结果显示REM睡眠期间的梦并 不受清醒状况的影像, 因为在狵哑人士的梦中他们 可以不借助手语说话, 而在半身不遂被试的梦中他 们可以自主行动, 似乎更支持做梦与清醒状态不连 续的模型 ${ }^{[76]}$.

各方对做梦与清醒是否是连续的仍存在争议, 某种程度上可能这两者是兼具的 ${ }^{[34]}$. 也许一种特殊 的梦的形式会为这个问题的讨论带来新的角度, 即 清醒梦 (lucid dreaming), 在这种梦中做梦的人可以意 识到正在做梦 ${ }^{[77]}$. 有学者认为清醒梦是一种意识的 混合状态, 同时包括了清醒和做梦的特点 ${ }^{[78]}$, 清醒 梦多发生于REM睡眠期间, 但最近有研究发现 NREM睡眠中也可出现清醒梦 ${ }^{[79]}$. 清醒梦中人们同 时具有初级意识和包括抽象逻辑思维、元认知、意志 力、洞察力等心理活动的次级意识 ${ }^{[00,81]}$, 因此被认为 是唯一一个可以利用来同时对比研究初级意识和次 级意识的现象 ${ }^{[82]}$.

\section{4 梦研究的挑战和有趣的方向}

如前所述由于梦的普遍性和神秘性以及作为意 识的重要组成部分, 近些年日益吸引了大量的研究 者投身于对这个有趣现象的研究, 但这是一个充满 挑战的领域.

目前梦的研究主要依赖于对于梦的自我报告, 缺乏对梦客观的评估. 人们对于梦的主管报告受多 种因素的影响. 一方面可能来自报告者, 尤其是相关 的能力水平, 如语言能力, 对梦进行口头报告时可能 会直接影响梦的描述, 再如记忆力, 梦的报告是回溯 性的, 人们有低估和忘记自己梦的倾向, 这被称为梦 的健忘(dream amnesia) ${ }^{[5]}$; 报告者自身的一些心理状 况, 如态度压力等会影响梦的报告, 对梦感兴趣、持 积极态度的人更容易报告做梦 ${ }^{[83]}$; 此外由于梦的内 容可能涉及报告者的隐私或道德禁忌, 如涉及性和 暴力的幻想, 也会影响梦的报告 ${ }^{[72]}$. 另一方面梦收 集过程中的因素, 如时间、地点等也会对梦的报告产 生影响 ${ }^{[5]}$. 如最近的一项研究表明梦的报告受在家还 是在实验室的影响, 这种影响与收集梦的夜晚效应、 睡眠环境、报告的程序等因素有关 ${ }^{[84]}$. 因此在梦的研
究中一些可以减少收集环节影响的实验设计是格外 推荐的, 如被试内设计, 同时尽可能在梦产生接近的 时间点进行收集(早晨或在睡眠中唤醒) ${ }^{[48]}$. 此外随着 技术的进步可以结合一些新的脑成像技术, 如功能 近红外光谱技术(functionality near infrared spectroscopy, fNIRs)改进梦的收集方式, 提高梦的报告的信 度 $^{[85]}$.

随着研究技术的进步, 神经生理和神经影像学 的加人大大丰富和深人了我们对于梦理解. 神经影 像学的方法如正电子发射断层成像(positron emission tomography, PET) 和最近更为常用的功能性磁共振成 像(functional magnetic resonance imaging, fMRI). $\mathrm{fMRI}$ 允许重复非侵人性的对大脑功能的变化进行高 清晰度的测量. 不过由于fMRI本身的一些限制, 使 得这项技术应用于梦的研究时有一些潜在的困难, 如严格的头部固定, 而且梦发生于睡眠中, 仪器的噪 声可能也会对梦产生影响 ${ }^{[23,64]}$. 另一方面由于对梦 的分析依赖于主观报告, 需要打断睡眠过程来收集 信息, 但这对fMRI的操作是不容易的 ${ }^{[48]}$, 而EEG由 于适宜于睡眠过程中反复唤醒的模式被称为对梦研 究的“金标准方法” “66]. 鉴于这两种技术各有利弊, 目 前一个趋势是将两种技术整合使用, 即同步脑电和 功能磁共振成像( simultaneous electroencephalographyfunctional magnetic resonance imaging, EEG-fMRI) ${ }^{[6,86]}$. fMRI技术是探索梦的神经生物机制的有效研究手段, 然而它记录的是外部刺激下大脑的激活情况, 另外 一些技术如脑刺激方法可以通过向大脑皮层直接施 加可操作的刺激, 也是研究梦的神经基础的重要工 具, 包括经颖磁刺激 (transcranial magnetic stimulation, TMS), 经颅直流电刺激法 (transcranial direct current stimulation, tDCS), 经颅交流电刺激法 (transcranial alternating current stimulation, tACS) 等 ${ }^{[50]}$. 如采用 $\mathrm{tDCS}$, 通过向大脑特定区域的皮层施加恒定、 低强度的直流电(1 2 mA), 可增强(阳极刺激)刺激部 位神经元或降低(阴极刺激)该部位神经元的兴奋性, 有研究表明在睡眠的不同阶段对前额叶和后顶叶皮 层施加 tDCS 刺激, 对梦产生了不同的影响：阴极刺 激前额叶同时阳极刺激顶叶时，增强了睡眠第二阶 段梦的视觉影像, 但这种效应没出现在慢波睡眠阶 段, 当阴极刺激顶叶, 阳极刺激额叶时, REM睡眠阶

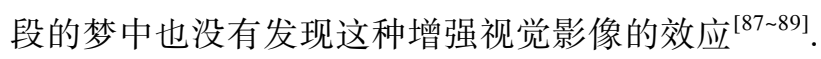
梦的奥秘日益引发研究者的兴趣, 其中一些方 
面的研究可能对于推动对于梦的理解有着重要的作 用. 首先是对于睡眠全过程的研究, 在梦的研究早期 阶段大多数研究集中于 REM睡眠, 随着 NREM睡眠 梦的研究的增加, 这两种睡眠阶段中大脑活动的相 似和差异得到了更多的重视, 揭示这些异同将有助 于我们对整个睡眠周期梦的机制的了解. 同时, 如前 所述清醒梦作为一种特殊的意识状态兼具清醒和睡 眠的认知特点, 在大脑活动上呈现独特性, 不仅为了 解梦的神经机制也为揭示意识的神经机制提供了可 能的机会 ${ }^{[86]}$. 在梦的研究中采用对比的策略, 比较 做梦和清醒状况(包括正常的清醒, 病理性的清醒, 其他意识状态), 将有助于在一个更为广阔的视野中 了解梦的现象与机制 ${ }^{[90]}$.

在梦的研究中, 对特殊群体的研究往往能带来 突破性的结果, 如前所述Solms对脑损伤病人的研究 揭示了 REM睡眠和做梦的不完全对应性 ${ }^{[17]}$, 再如对 于先天残疾人士的研究表明了梦境与现实情况的差

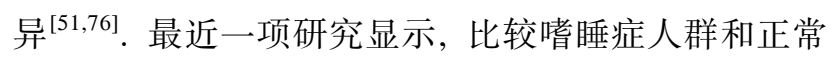
人群有助于对清醒梦的了解 ${ }^{[91]}$. 另外由于共同具有 复杂性、多变性和意识内容的离奇性, 精神疾病与做 梦可能存在很多重叠 ${ }^{[92]}$, 也获得了一些神经影像学 研究的支持, 如有研究发现在精神病患者的大脑活
动呈现了边缘系统过度激活而背外侧前额叶皮层活 动降低的模式 ${ }^{[40]}$, 这个模式与前文提到的做梦时的 大脑活动是相似的.

梦的研究还可能具有巨大的临床应用意义, 前 文有关梦的理论, 一些学者认为梦具有治疗的作用, 对于急性创伤的个体, 梦为他们提供了一个安全的 环境来进行疗愈 ${ }^{[29,31]}$, 而在心理治疗领域长期以来 对梦进行工作的传统不应被现代科学所遗忘, 相反 应该是梦科学研究的一个重要领域 ${ }^{[93]}$, 研究者们在 创伤、哥梦的治疗方面已经积累了重要的经验 ${ }^{[94]}$, 而 随着清醒梦研究的深人, 研究者们发现清醒梦在临 床治疗中的价值，尽管清醒梦的发生率不高，普通人 群中占全部梦的不足 $10 \%$, 确切数据仍有待确定 ${ }^{[95]}$, 不过清醒梦是可以通过技术诱导和训练产生的 ${ }^{[96]}$, 且研究显示清醒梦可应用于临床对䔅梦的治疗 ${ }^{[77,97]}$.

总之, 人类对于梦一直抱有天然的兴趣和好奇, 梦的研究对于我们了解人类的进化和发展, 大脑的 工作特点, 意识的形成和演变等问题有着重要的意 义. 现代科学技术提供了更多的方法和手段去了解 梦、揭示梦的神经基础, 然而这方面的研究方兴未艾, 关于我们为什么会做梦迄今尚无明确的答案, 梦的 很多奥秘仍等待解开.

\section{参考文献}

1 Fisher S P, Foster R G, Peirson S N. The circadian control of sleep. In: Kramer A, Merrow M, eds. Circadian Clocks. Handbook of Experimental Pharmacology, vol 217. Berlin, Heidelberg: Springer, 2013

2 Saper C B, Fuller P M, Pedersen N P, et al. Sleep state switching. Neuron, 2010, 68: 1023-1042

3 Vyazovskiy V V, Delogu A. NREM and REM sleep: Complementary roles in recovery after wakefulness. Neuroscientist, 2014, 20: 203-19

4 Iber C, Ancoli-Israel S, Chesson A L, et al. The AASM Manual for the Scoring of Sleep and Associated Events: Rules, Terminology, and Technical Specifications. Westchester, IL: American Academy of Sleep Medicine, 2007

5 Nir Y, Tononi G. Dreaming and the brain: From phenomenology to neurophysiology. Trends Cogn Sci, 2010, 14: 88-100

6 Lei X, Liu H, Li H. A survey of simultaneous EEG-fMRI on sleep (in Chinese). Adv Psychol Sci, 2013, 21: 448-457 [雷旭, 刘欢, 李红. 睡眠的同步 EEG-fMRI 研究述评. 心理科学进展, 2013, 21: 448-457]

7 Liu X J. Analysis of Chuang-tzu's “dream” (in Chinese). WenJiao ZiLiao, 2008, (28): 4-5 [刘学军. 《庄子》“梦”的解析. 文教资料, 2008, (28): 4-5]

8 Stevens A. Private Myths: Dreams and Dreaming. Cambridge, Massachusetts: Harvard University Press, 1997

9 Franklin M S, Zyphur M J. The role of dreams in the evolution of the human mind. Evol Psychol, 2005, 3: 59-78

10 Hobson J A. The Dreaming Brain. New York: Basic Books, 1988

11 Hobson J A, McCarley R W. The brain as a dream state generator: An activation-synthesis hypothesis of the dream process. Am J Psychiatry, 1977, 134: 1335-1348

12 Crick F, Mitchison G. The function of dream sleep. Nature, 1983, 304: 111-114

13 Crick F, Mitchison G. REM sleep and neural nets. Behav Brain Res, 1995, 69: 147-155 
14 Foulkes D. Dreaming: A Cognitive-Psychological Approach. Hillsdale, NJ: Lawrence Erlbaum Associates, 1985

15 Freud S. The Interpretation of Dreams. London: Penguin, 1900

16 Jung C. Dreams. Princeton, NJ: Princeton University Press, 1974

17 Solms M. Dreaming and REM sleep are controlled by different brain mechanisms. Behav Brain Sci, 2000, 23: 843-850

18 Johnson B, Mosri D F. The neuropsychoanalytic approach: Using neuroscience as the basic science of psychoanalysis. Front Psychol, 2016, 7: 1459

19 Solms M, Turnbull O H. What is neuropsychoanalysis? Neuropsychoanalysis, 2011, 13: 133-145

20 Domhoff G W. A new neurocognitive theory of dreams. Dreaming, 2001, 11: 13-33

21 Domhoff G W. The neural substrate for dreaming: Is it a subsystem of the default network? Conscious Cogn, 2011, 20: 1163-1174

22 Eiser A S. Physiology and psychology of dreams. Semin Neurol, 2005, 25: 97-105

23 Desseilles M, Dang-Vu T T, Sterpenich V, et al. Cognitive and emotional processes during dreaming: A neuroimaging view. Conscious Cogn, 2011, 20: 998-1008

24 Rasch B, Born J. About sleep's role in memory. Physiol Rev, 2013, 93: 681-766

25 Cipolli C, Fagioli I, Mazzetti M, et al. Incorporation of presleep stimuli into dream contents: Evidence for a consolidation effect on declarative knowledge during REM sleep? J Sleep Res, 2004, 13: 317-326

26 Wamsley E J. Dreaming and offline memory consolidation. Curr Neurol Neurosci Rep, 2014, 14: 433-443

27 Murkar A, Smith C, Dale A, et al. A neuro-cognitive model of sleep mentation and memory consolidation. Int J Dream Res, 2014, 7: $85-89$

28 Zhang J. Continual-Activation Theory of Dreaming. DynaPsych, 2006

29 Hartmann E. Outline for a theory on the nature and functions of dreaming. Dreaming, 1996, 6: 147-170

30 Levin R, Nielsen T. Nightmares, bad dreams, and emotion dysregulation: A review and new neurocognitive model of dreaming. Curr Dir Psychol Sci, 2009, 18: 84-88

31 Hartmann E. The Nature and Functions of Dreaming. Oxford: Oxford University Press, 2010

32 Revonsuo A. The reinterpretation of dreams: An evolutionary hypothesis of the function of dreaming. Behav Brain Sci, 2000, 23: 877-901

33 Valli K, Revonsuo A. The threat simulation theory in light of recent empirical evidence: A review. Am J Psychol, 2009, 122: 17-38

34 Blagrove M. Distinguishing continuity/discontinuity, function and insight when investigating dream content. Int J Dream Res, 2011, 4: $45-47$

35 Aserinsky E, Kleitman N. Regularly occurring periods of eye motility, and concomitant phenomena, during sleep. Science, 1953, 118: $273-274$

36 Dement W, Kleitman N. Cyclic variations in EEG during sleep and their relation to eye movements, body motility, and dreaming. Electroencephalogr Clin Neurophysiol, 1957, 9: 673-690

37 Nielsen T A. A review of mentation in REM and NREM sleep: 'Covert' REM sleep as a possible reconciliation of two opposing models. Behav Brain Sci, 2000, 23: 851-866

38 Solms M. The Neuropsychology of Dreams: A Clinico-anatomical Study. New York: Psychology Press, 2014

39 Foulkes W D. Dream reports from different stages of sleep. J Abnorm Soc Psychol, 1962, 65: 14-25

40 Limosani I, D'agostino A, Manzone M L, et al. The dreaming brain/mind, consciousness and psychosis. Conscious Cogn, 2011, 20: 987-92

41 Oudiette D, Dealberto M J, Uguccioni G, et al. Dreaming without REM sleep. Conscious Cogn, 2012, 21: 1129-1140

42 Braun A R, Balkin T J, Wesensten N J, et al, Dissociated pattern of activity in visual cortices and their projections during human rapid eye movement sleep. Science, 1998, 279: 91-95

43 Maquet P, Laureys S, Peigneux P, et al. Experience-dependent changes in cerebral activation during human REM sleep. Nat Neurosci, 2000, 3: 831-836

44 Maquet P, Péters J M, Aerts J, et al. Functional neuroanatomy of human rapid eye-movement sleep and dreaming. Nature, 1996, 383: $163-166$

45 Nofzinger E A, Mintun M A, Wiseman M, et al. Forebrain activation in REM sleep: An FDG PET study. Brain Res, 1997, 770: 192-201

46 Pace-Schott E F. The neurobiology of dreaming. In: Kryger M H, Roth T, Dement W C, eds. Principles and Practice of Sleep Medicine. 5th ed. Philadelphia: Elsevier, 2009

47 Hobson J A, Pace-Schott E F, Stickgold R, et al. Dreaming and the brain: Toward a cognitive neuroscience of conscious states. Behav Brain Sci, 2000, 23: 793-842

48 Kussé C, Muto V, Mascetti L, et al. Neuroimaging of dreaming: state of the art and limitations. Int Rev Neurobiol, 2010, 92: 87-99

Maquet P. Functional neuroimaging of normal human sleep by positron emission tomography. J Sleep Res, 2000, 9: 207-231 
50 Mutz J, Javadi A H. Exploring the neural correlates of dream phenomenology and altered states of consciousness during sleep. Neurosci Conscious, 2017, 3: 1-12

51 Bértolo H, Paiva T, Pessoa L, et al. Visual dream content, graphical representation and EEG alpha activity in congenitally blind subjects. Cogn Brain Res, 2003, 15: 277-284

52 Schredl M. Characteristics and content of dreams. Int Rev Neurobiol, 2010, 92: 135-154

53 Nielsen T, Stenstrom P, Takeuchi T, et al. Partial REM-sleep deprivation increases the dream-like quality of mentation from REM sleep and sleep onset. Sleep, 2005, 28: 1083-1089

54 Foulkes D, Schmidt M. Temporal sequence and unit composition in dream reports from different stages of sleep. Sleep, 1983, 6: 265-280

55 Wamsley E, Hirota Y, Tucker M A, et al. Circadian and ultradian influences on dreaming: A dual rhythm model. Brain Res Bull, 2007, 71: 347-354

56 McNamara P, Johnson P, McLaren D, et al. REM and NREM sleep mentation. Int Rev Neurobiol, 2010, 92: 69-86

57 Bucci A, Grasso M. Sleep and dreaming in the predictive processing framework. In: Metzinger T K, Wiese W, eds. Philosophy and Predictive Processing. Frankfurt am Main: MIND Group, 2017

58 Siclari F, Baird B, Perogamvros L, et al. The neural correlates of dreaming. Nat Neurosci, 2017, 20: 872-878

59 Hobson J A, Stickgold R. Dreaming: a neurocognitive approach. Conscious Cogn, 1994, 3: 1-15

60 Nielsen T A. Mentation during sleep: the NREM/REM distinction. In: Lydic R, Baghdoyan H A, eds. Handbook of Behavioral State Control: Cellular and Molecular Mechanisms. Boca Raton, FL: CRC Press, 1999. 101-128

61 Kjaer T W, Law I, Wiltschiotz G, et al. Regional cerebral blood flow during light sleep-a H15 O-PET study. J Sleep Res, 2002, 11: 201-207

62 Fox K C, Nijeboer S, Solomonova E, et al. Dreaming as mind wandering: Evidence from functional neuroimaging and first-person content reports. Front Hum Neurosci, 2013, 7: 1-18

63 Cipolli C, Ferrara M, De Gennaro L, et al. Beyond the neuropsychology of dreaming: Insights into the neural basis of dreaming with new techniques of sleep recording and analysis. Sleep Med Rev, 2017, 35: 8-20

64 Domhoff G W, Fox K C. Dreaming and the default network: A review, synthesis, and counterintuitive research proposal. Conscious Cogn, 2015, 33: 342-53

65 Herlin B, Leu-Semenescu S, Chaumereuil C, et al. Evidence that nondreamers do dream: A REM sleep behaviour disorder model. J Sleep Res, 2015, 24: 602-609

66 Scarpelli S, Gennaro L D. Electrophysiological pattern of dream experience. J Public Health Emerg, 2017, 1: 1-6

67 Revonsuo A. Inner Presence: Consciousness as a Biological Phenomenon. Cambridge, MA: The MIT Press, 2006

68 Domhoff G W. Dreams are embodied simulations that dramatize conceptions and concerns: The continuity hypothesis in empirical, theoretical, and historical context. Int J Dream Res, 2011, 4: 6-18

69 Schredl M, Hofmann F. Continuity between waking activities and dream activities. Conscious Cogn, 2003, 12: 298-308

70 Graveline Y M, Wamsley E J. Dreaming and waking cognition. Transl Issues Psychol Sci, 2015, 1: 97-105

71 Hobson J A. REM sleep and dreaming: Towards a theory of protoconsciousness. Nat Rev Neurosci, 2009, 10: 803-813

72 Schwartz S, Maquet P. Sleep imaging and the neuropsychological assessment of dreams. Trends Cogn Sci, 2002, 6: 23-30

73 De Gennaro L, Marzano C, Cipolli C, et al. How we remember the stuff that dreams are made of: Neurobiological approaches to the brain mechanisms of dream recall. Behav Brain Res, 2012, 226: 592-596

74 Wamsley E J, Stickgold R. Dreaming and offline memory processing. Curr Biol, 2010, 20: 1010-1013

75 Lee M N, Kuiken D. Continuity of reflective awareness across waking and dreaming states. Dreaming, 2015, 25: 141-159

76 Voss U, Tuin I, Schermellah K, et al. Waking and dreaming: Related but structurally independent. Dream reports of congenitally paraplegic and deaf mute persons. Conscious Cogn, 2011, 20: 673-687

77 Spoormaker V I, van den Bout J. Lucid dreaming treatment for nightmares: A pilot study. Psychother Psychosomat, 2006, 75: 389-394

78 Voss U, Holzmann R, Tuin I, et al. Lucid dreaming: A state of consciousness with features of both waking and non-lucid dreaming. Sleep, 2009, 32: 1191-200

79 Stumbrys T, Erlacher D. Lucid dreaming during NREM sleep: Two case reports. Int J Dream Res, 2012, 5: 151-155

80 Voss U, Schermelleh-Engel K, Windt J, et al. Measuring consciousness in dreams: The lucidity and consciousness in dreams scale. Conscious Cogn, 2013, 22: 8-21

81 Dresler M, Eibl L, Fischer C F, et al. Volitional components of consciousness vary across wakefulness, dreaming and lucid dreaming. Front Psychol 2014, 4: 987

82 Spoormaker V I, Czisch M, Dresler M. Lucid and non-lucid dreaming: Thinking in networks. Int J Dream Res, 2010, 3: 49-51 
83 Beaulieu-Prevost D, Zadra A. Absorption, psychological boundaries and attitude towards dreams as correlates of dream recall: Two decades of research seen through a meta-analysis. J Sleep Res, 2007, 16: 51-59

84 Sikka P, Revonsuo A, Sandman N, et al. Dream emotions: A comparison of home dream reports with laboratory early and late REM dream reports. J Sleep Res, 2017, 1-9

85 Dresler M, Koch S P, Wehrle R, et al. Dreamed movement elicits activation in the sensorimotor cortex. Curr Biol, 2011, 21: 1833-1837

86 Dresler M, Wehrle R, Spoormaker V I, et al. Neural correlates of dream lucidity obtained from contrasting lucid versus nonlucid REM sleep: A combined EEG/fMRI case study. Sleep, 2012, 35: 1017-1020

87 Jakobson A J, Conduit R D, Fitzgerald P B. Investigation of visual dream reports after transcranial direct current stimulation (tDCS) during REM sleep. Int J Dream Res, 2014, 5: 87-93

88 Jakobson A J, Fitzgerald P B, Conduit R. Investigation of dream reports after transcranial direct current stimulation (tDCs) during slow wave sleep (SWS). Sleep Biol Rhythms, 2012, 10: 169-178

89 Jakobson A J, Fitzgerald P B, Conduit R. Induction of visual dream reports after transcranial direct current stimulation (tDCs) during Stage 2 sleep. J Sleep Res, 2012, 21: 369-379

90 Windt J M, Noreika V. How to integrate dreaming into a general theory of consciousness-A critical review of existing positions and suggestions for future research. Conscious Cogn, 2011, 20: 1091-1107

91 Dodet P, Chavez M, Leu-Semenescu S, et al. Lucid dreaming in narcolepsy. Sleep, 2015, 38: 487-497

92 Collerton D, Perry E. Dreaming and hallucinations-continuity or discontinuity? Perspectives from dementia with Lewy bodies. Conscious Cogn, 2011, 20: 1016-1020

93 Bulkeley K. The future of dream science. Ann N Y Acad Sci, 2017, 1406: 68-70

94 Kramer M, Glucksman M L. Dream Research: Contributions to Clinical Practice. New York: Routledge, 2015

95 Zink N, Pietrowsky R. Theories of dreaming and lucid dreaming: An integrative review towards sleep, dreaming and consciousness. Int J Dream Res, 2015, 8: 35-53

96 Aspy D J, Delfabbro P, Proeve M, et al. Reality testing and the mnemonic induction of lucid dreams: Findings from the national Australian lucid dream induction study. Dreaming, 2017, 27: 206-231

97 Spoormaker V I, van den Bout J, Meijer E J. Lucid dreaming treatment for nightmares: A series of cases. Dreaming, 2003, 13: 181-186



\section{陈社姘}

中国科学院心理健康重点实验室(中国科学院心理研究所) 副研究员, 中国心 理学会医学心理专业委员会委员, 中国心理学会心理学标准与服务研究委员 会委员, 中国心理学会科普专业委员会委员, 中国心理学会临床与咨询委员 会首批注册督导师, 中国科学院心理研究所国民心理健康评估发展中心负责 人. 主要研究领域包括国民心理健康状况调查、青少年心理健康追踪研究、 心理健康应用测评及干预。 


\title{
The bizarreness and reality of dreams
}

\author{
Fei Guo \& Zhiyan Chen ${ }^{*}$ \\ CAS Key Laboratory of Mental Health, Institute of Psychology, Chinese Academy of Sciences, Beijing 100101, China \\ * Corresponding author, E-mail: chenzy@ psych.ac.cn
}

Dreams are one of the most common experience in our lives. The vivid and bizarre features of dreams have fascinated humankind throughout history. Dreaming is an ancient physiological and psychological phenomenon, and whether it fulfils an adaptive function has inspired varied theories. Some theories take a perspective that dreaming serves no adaptive function but rather a biologically epiphenomena. Some theories claim that dreaming fulfill various neurophysiological functions. However, the dream contents are viewed as random noise generated by the sleeping brain. Other theories believe that what appears in dreams is important since it serves functions which relate to psychological adjustment. More recent theories tend to relate dreaming to intellectual or cognitive functions, such as learning, memory consolidation, problem solving or simulating of threats in real life.

The enigma of dreams is extensively studied with the development of science technology. Although the dream science was initiated from the REM (rapid eye movement sleep) sleep dreams, the equation "REM=dreaming" is an oversimplification. Dream-like mentation may occur during all stages of sleep. The controversy now is whether dreams reported from REM and NREM (non-rapid eye movement sleep) sleep are equivalent or different from each other. Three different theoretical models about the REM/NREM mentation have been proposed: (1) An one-generator model, which claims that regardless of the sleep stage in which the mention occurs, it only stems from a single set of process; (2) a two-generator model, which holds a perspective that REM and NREM mentions have differentiated generation systems; (3) a covert REM sleep model, which assumes that the NREM sleep dream is generated from the covert activity that occurs in REM sleep. Since there are experimental evidences supported both the similarities and differentiation in phenomenological aspects and the underlying brain activities of REM and NREM sleep dream, it is still controversial which model is the most optimal interpretation for the two mentation.

The dream is a special state of consciousness. The continuity and discontinuity between waking and dreaming has been a controversy in dream science. The similarities and differences in both phenomenon and brain activity between dreaming and waking provide important knowledge of human consciousness, especially lucid dreaming, a hybrid state of consciousness with features of both waking and dreaming, which provides an unique chance to reveal the neural basis of consciousness. Moreover, dream studies are significant in the clinical practice in psychiatry and psychology.

Although advances in neurophysiological and neuroimaging methods have offered new insight into the brain correlates of dreaming, the private nature of dreaming has made it a formidable study object. The studies of dreaming are still confronted with methodological challenges. To reveal the mystery of dreaming, integration of the designs and methods from multiple fields (such as phenomenology, neuroscience, clinical practice, etc) is necessary.

dream, dreaming, sleep, consciousness, neurosciences

doi: 10.1360/N972017-00944 